\section{Saddik M. Gohar}

Saddik M. Gohar is Associate Professor in the Department of English, United Arab Emirates University, Al-Ain, Abu Dhabi, United Arab Emirates. E-mail:saddik59@yahoo.com

\author{
The dialectics of homeland and \\ identity: Reconstructing Africa in the \\ poetry of Langston Hughes \\ and Mohamed Al-Fayturi
}

\title{
Reconstructing Africa in the poetry of Langston Hughes and Mohamed Al-Fayturi .
}

The article investigates the dialectics between homeland and identity in the poetry of the Sudanese poet, Mohamed Al-Fayturi and his literary master, Langston Hughes in order to underline their attitudes toward crucial issues integral to the African and AfricanAmerican experience such as identity, racism, enslavement and colonisation. The article argues that - in Hughes's early poetry Africa is depicted as the land of ancient civilisations in order to strengthen African-American feelings of ethnic pride during the Harlem Renaissance. This idealistic image of a pre-slavery, a pre-colonial Africa, argues the paper, disappears from the poetry of Hughes, after the Harlem Renaissance, to be replaced with a more realistic image of Africa under colonisation. The article also demonstrates that unlike Hughes, who attempts to romanticize Africa, Al-Fayturi rejects a romantic confrontation with the roots. Interrogating western colonial narratives about Africa, Al-Fayturi reconstructs pre-colonial African history in order to reveal the tragic consequences of colonisation and slavery upon the psyche of the African people. The article also points out that in their attempts to confront the oppressive powers which aim to erase the identity of their peoples, Hughes and Al-Fayturi explore areas of overlap drama between the turbulent experience of African-Americans and the catastrophic history of black Africans dismantling colonial narratives and erecting their own cultural mythology. Key words: Slavery, colonisation, racism, identity.

Black people in Africa and the United States of America are bound to each other by their common colour and their legacy of slavery and oppression. The majority of the black people in the U.S. A. share a common attitude and a worldview toward Africa with varying intensities, which is distinct from that of white Americans and Europeans. Due to a variety of reasons, the African-American experience has shaped the attitude of the black people in the U. S. A. toward Africa. As a result of the long historical detachment of America from Africa, the African-American personality is spiritually and culturally distanced from its roots, nevertheless, Africa has occupied a significant position in African-American literature since the 1920s. In his article, "Black Nationalism since Garvey", John Bracey establishes an analogy between the black experience in the U.S. A. and the history of the black people in Africa:

The black experience in America can be viewed as similar to the colonial experience of blacks in Africa, the West Indies, and Latin America. The historical process in 
these areas - colonization, resistance, accommodation, nationalism, de-colonisation, nationhood - is operable in Black America. The corresponding historical continuum in America, then, is colonialism (slavery), 1619-1865, colonialism (imperialism), 1865-1963, and de-colonization, since 1963 (Bracey 1971: 259).

In Rebellion or Revolution, Harold Cruse affirms Bracey's argument by drawing a link between the circumstances of Africans under western colonisation and the black experience of racism and slavery in the U.S. A. In his discussion of what he calls the state of "domestic colonization" of blacks in America, Cruse (1968: 77) argues: "It is not at all remarkable then that the semi-colonial status of the Negro has given rise to nationalist movements. It could be surprising if it had not". The similarity between the African and the African-American experience of racism, slavery and colonisation leads to the emergence of black nationalist movements which have their roots in African and American history:

Black nationalism has deep roots in American history. Black nationalism as a body of ideas and a pattern of behavior stemming logically from the colonial relationship of Black America to White America is both a response to colonial subordination and an affirmation of the existence of an alternative nationality and set of values (Bracey 1971: 259).

In other words, the emergence of black nationalist movements is the result of the conflict between blacks and whites in Africa and the New World leading to persecution, enslavement and genocide. In Africa, the European colonisers deprived blacks of their languages and traditions in an attempt to impose western cultural paradigms on a persecuted and colonised people. And in the New World, the white oppressors degraded black culture, rituals and religious beliefs categorising them as inferior, primitive and pre-historic. In the U. S. A., long-term slavery stripped the black people of their cultural heritage and African traditions. During the slave era, the environment in the southern parts reinforced in black Americans feelings of shame and repulsion about Africa. And these times, Africa was conceived as a pagan land, a pre-historic continent where savages adopt a barbaric life-style antagonistic to the West. In The Souls of Black Folks (1968), W. E. B. DuBois (1968: 368) argues that in the South, the Negro was forbidden from turning to Africa for cultural nourishment in addition of being prohibited from learning the American culture: "he [the slave] felt his poverty; without a cent, without a home, without land, tools, or savings, he had entered into competition with rich, landed skilled neighbours. To be a poor man is hard, but to be a poor race in the land of dollars is the very bottom of hardship".

However, the processes of slavery and colonialism which attempt to strip blacks of their identity result in the formation of counter movements in the U. S. A. and 
Africa that aim to restore and emphasise black ethos and culture. For example, advocates of reverse movements such as négritude and Pan-Africanism are engaged in a series of revolts against colonisation propagating the unifying essence of black culture and calling for unity among peoples of African origin throughout the world. In the U.S. A., some of these movements called for the return of black Americans to Africa to establish an African power capable of gaining the admiration of the world. As early as the eighteenth century, African-American writers defended the dignity of Africa and its people against western colonisation and racism. Likewise, AfricanAmerican scholars and international writers of African descent such as Aimé Césaire and Léopold Sédar Senghor also defended the downtrodden people of Africa who have been dehumanised by those motivated by the economics of slavery. W. E. B. DuBois in The World and Africa (1947) illustrates the significance of Africa as a unifying force for the black people all over the world:

The idea of one Africa to unite the thought and ideals of all native peoples of the Dark Continent belongs to the twentieth century and stems naturally from the West Indies and the Unites States. Here, various groups of Africans, quite separate in origin, became so united in experience and so exposed to the impact of new cultures that they began to think of Africa as one idea and one land. (DuBois 1947: 7)

The racial solidarity or the belief that black people are linked together by their colour and African descent draws them closer to Africa. DuBois made the point that the Africans transported to America "from the fifteenth through the seventeenth centuries considered themselves as temporary settlers destined to return eventually to Africa;" according to him, "their increasing revolts against the slave system, which culminated in the eighteenth century showed a feeling of close kinship to the mother land and even well into the nineteenth century they called their organisations 'African', as witness the 'African unions' of New York and Newport, and the African Churches of Philadelphia and New York" (cited in Essien-Udom 1971: 234).

The awareness of the African component of their racial identity drives the African-Americans to sympathize with the African countries, which attained their independence in the 1950s and 1960s merging "their aspirations for equality in America with the aspirations of the exploited peoples of the Third World" (Essien-Udom 1971: 233). In spite of the common ties that bound blacks in America and Africa, Martin Luther King jr. points out that "the Negro must face the fact that America is now his home" undermining the argument which links the liberation of African-Americans with the liberation of the down-trodden nations all over the world: "Arguments that the American Negro is a part of a world which is two-thirds colored and that there will come a day when the oppressed people of color will violently rise together to throw off the yoke of white oppression, are beyond the realm of serious discussion" (King 1969: 57). 
Regardless of King's view, black people, in Africa and the U. S. A. share a history of suffering and an ancestral memory of agony and pain reflected in their literatures and folklore traditions. The complexities and intensities of the history of race relations and colonisation in Africa and Black America (a domestic colony) gave rise to a literature of protest manifesting itself in the works of Al-Fayturi and Hughes, particularly in his poetry after the Harlem Renaissance.

As an objective observer of human actions, particularly those that grew out of the racial situation in the U. S. A. during the 1920s and 1930s, Langston Hughes explores the complex relationship between the African-American and his ethnic roots in Africa. The African-American insists on achieving his dream of equality and dignity by returning to Africa after his confrontation with white American arrogance and superiority. Therefore, in Hughes's poetry, the African-American longs for Africa not only because of an intense identity crisis but also as a result of the racial situation in America. Because white racism and oppression delayed the full realisation of black dreams, African-Americans turn to Africa seeking solace, consolation and support. Hughes (1974: 14) points out that in Africa the African-American will be able to

fling my arms wide

in some place of the sun,

to whirl and to dance

till the white day is done

then rest at cool evening

beneath a tall tree

while night comes on gently,

dark like me.

Since Africa, in the words of Richard Barksdale (1977: 21), "represented an artistic symbol and a political refuge for blacks", Hughes's longing for Africa is an indication of his rejection of the racist values of the U. S. A. In his early poetry in The Weary Blues he protests his being taken from the African motherland to be "caged in the circus of civilization" (Hughes 1926: 100). The poet feels like a stranger in America: "We cry among the skyscrapers / As our ancestors / cried among the palms in Africa" (102). Hughes also speaks about "the jungle joys" associating the "night-dark girl of the swaying hips" who dances in a Harlem cabaret, in the 1920s, with the jungle trees of Africa bathed in the splendour of a tropical "starwhite moon". Such longing for Africa, particularly in Hughes's early poetry, has a romantic feature simply because it does not depict a real image of Africa but an Africa of the young poet's fantasy and imagination.

In Hughes's early poems, Africa is an unattainable ideal, a foil for his vision of a racist America where blacks are dehumanised. As a tropical paradise, a land of palms, 
forests and sun, Africa is contrasted with America which is delineated as a waste land and moral wilderness. Prior to colonisation and slavery, Africans, according to Hughes' poetry, were living in a natural environment but in a post-slavery era, they are suffocated in the circus of American civilisation. Caught in a world of skyscrapers and industrial smog, the African-American poet feels tired and his soul becomes "empty as the silence" (103). In America, states Hughes, the black people suffer from alienation and dispossession, thus, they escape in the blues and other black folk songs which remind them of Africa. Further, the black folks, in Harlem city, are captured by Hughes in a sophisticated way revealing their longing for return to the innocence of their African past:

I would be simple again

simple and clean

like the earth

like the rain. (104)

This romanticization of Africa is one of the basic characteristics of Hughes's early poetry during the Harlem Renaissance where an image of an idealistic, pre-colonial Africa is integral to the emerging feelings of ethnic pride among AfricanAmericans at that time. Like Hughes, Mohamed Al-Fayturi is drawn to Africa as a result of a deeply rooted awareness of his African origins. ${ }^{1}$ Regardless of the differences between the two poets concerning their treatment of the African motif, both of them revealed sympathy toward the plight of the black people in Africa and all over the world. Writing about Africa in Arabic, Al-Fayturi, according to Ali Shalash (1993: 29) "distinguished himself from other African writers who used the language of the coloniser. Denouncing imperialist narratives which promote the integration of colonial languages in native literatures, Najuib Saleh (1984: 16) glorifies Al-Fayturi as the first poet who sings for Africa in Arabic: "Al-Fayturi is the spokesman of the Arab Africans who constitute two thirds of the population of the Arab world. He expresses their pains and weaknesses in his poetry."2

As the first poet who explores the tragic experience of the African people, in Arabic language, Al-Fayturi not only addresses Arab Africans, as Saleh claims, but also attempts to reach black people in Africa and all over the world. Being aware of his ethnic roots, Al-Fayturi, like his literary master, Langston Hughes, devotes his poetry to the black cause expressing sympathy toward a people who have been historically humiliated, persecuted and brutalised in their homeland and in the Diaspora. ${ }^{3}$

Scrutinising the African motif in the poetry of Al-Fayturi and Hughes, it becomes obvious that both poets incorporate African images revealing a longing for return to their roots evoking Africa in idealised terms. They dealt with Africa as their Zion, a Moses-like homeland; nevertheless, Al-Fayturi's Africa is different from the Africa of 
his black American counterpart. As a result of centuries of colonialism and slavery which have disfranchised him from his roots, Hughes is aware of the impossibility of returning physically to Africa. Therefore, his treatment of the African motif is coupled with a sense of homelessness born out of the feeling of being persecuted in the country where he lives as a victim of the legacy of racism and slavery. However, Hughes shares a feeling of ambivalence toward Africa with Al-Fayturi because both of them are racial and cultural hybrids suffering from alienation and an identity crisis determined by psychological, socio-political and cultural factors. While both of them are psychologically split between their ethnic origins and their place of birth, Hughes' identity crisis is deeper because he suffers from what DuBois calls "double consciousness". In The Souls of Black Folks DuBois refers to the crisis of being both black and American, of living in a limbo without a sense of belonging either to America or Africa:

It is a peculiar sensation, this double consciousness, this sense of always looking at one's self through the eyes of others, of measuring one's soul by the tape of a world that looks on in amused contempt and pity. One ever feels his twoness, an American, a Negro, two souls, two thoughts, two unreconciled strivings, two warring ideals in one dark body, whose dogged strength alone keeps it from being torn asunder (DuBois 1968: 3).

It is striking to argue that whether the loss of identity is individual or ethnic, the person subjected to this experience usually fights ferociously to avoid being lost in the labyrinth of cultures. Therefore, Al-Fayturi (1979a: 25-26) considers himself as an African poet, that his poetry is devoted to Africa and the black people in general. In his reply to critics who attempt to underestimate his volume Aghani Efriqya due to ideological differences, the poet says "you can not understand the reality of my tragedy because you did not pass through my painful experience". He argues that he does not want to distort the ugly reality of the African history of slavery and colonization: "I want to reveal the complicated feelings which came to us from the dilemma of the African experience. The era of slavery has left its scars on our bodies and souls" ${ }^{\prime \prime}$ (see appendix 1 ).

Unlike African and African-American poets who tend to romanticize Africa, Al-Fayturi ignores a poetics which seeks a romantic confrontation with the roots. For him black poetry involves an immersion in victimization and lyric slavery is unacceptable because it leads to alienation and distortion of history. In spite of blaming poets who create unrealistic images about Africa which may lead to a sense of alienation , Michele Goha (1999: 445) argues that Al-Fayturi expresses "a sense of solitude, exile and alienation" (appendix 2). Goha attributes this trend to the poet's feelings of exile after being cut off from his ethnic origin in black Africa as reflected, in "Resala Ela Al-Khartoum" ("A Message to Khartoum"): 


\author{
Lost in alien countries \\ dreaming of you \\ O my homeland \\ I creep on my sorrows \\ and the thorns of my bed \\ O my homeland \\ between us lies \\ a curtain of tears \\ and a wall of gunfire \\ coloured by catastrophes \\ $\mathrm{O}$, my aimless people \\ naked, tearful and dead \\ the wounded victims of history. (Al-Fayturi 1979a: 257, appendix 3)
}

Al-Fayturi's feelings of alienation and nostalgia as reflected in the poem cited above could also be attributed to personal factors. As a cultural and interracial hybrid, Al-Fayturi has not been able to reconcile the two parts of his mutilated self. For example, his experience in the city of Alexandria (Egypt) during World War II intensified the poet's ethnic consciousness as he observed the humiliation of the black people by the white European soldiers who participated in the war. Witnessing the miserable life conditions of the black people who were recruited from the Sudan to serve western soldiers during the war, Al-Fayturi (1979a: 43) expressed his desire to "escape from the city / from the evil of this vicious city" (Mahmud Amin Al-Alem's in Al-Fayturi 1979a: 41-54, appendix 4). Confronting the racism and injustice of what he calls "a city dominated by the white soldiers" Al-Fayturi reveals his antagonistic feelings toward Alexandria expressing his desire to be transformed into
a field worm
creeping into the holes of the earth
a wolf uncorrupted by the sins of the city
a blind child unable to see
the grudge and madness of the city. (Al-Fayturi 1979a: 45)

The poet's experience in the city of Alexandria during the 1940's intensified his identity crisis as he witnessed the daily humiliation of the black people at the hands of the European soldiers. Therefore, Al-Fayturi attempts, by all possible means, to emphasize his identity as a black African. In an interview, Al-Fayturi identifies himself as a poet who belongs to the African land (Ared Efriqya) in particular and to humanity (Al-Bashariyya) in general. He does not categorise himself as an Arab poet but he affirms: "My language is poetry, my motto is revolution and my 
weapon is truth. I am the first poet who sings for Africa in the Arabic language" (Saleh 1984: 144, appendix 5). ${ }^{5}$ Expressing the predicament of the African poet who is divided between his African roots and his Arab culture, Al-Fayturi affirms his identity as a black African. In "Ana Zinji" ("I am a Negro") he emphasizes this fact:

say it, do not be a coward

say it in the face of humanity

I am a Negro

Negro blood runs in the veins

of my parents

I am black

but I am free

Africa is my homeland

long live Africa. (Al-Fayturi 1979a: 80, appendix 6)

Al-Fayturi's insistence on his identity as black African is a compensation for the loss of his native language which is the basic "source of the native's problems" according to Isaac Yetiv. The loss of native language or what Yetiv (1976: 89) calls "the linguistic metamorphosis" constitutes part of the impetus behind Al-Fayturi's commitments to the African motif as expressed in his major volumes, Aghani Efriqya ("African songs", 1955), Ashiq min Ifriqya ("Lover from Africa", 1964), Uthkurini ya Efriqya ("Remember me Africa", 1966) and Ahzan Efriqya ("African sorrows", 1969).

In spite of his prolific poetic production that deals with Africa and African history, Al-Fayturi's Arabic poetry is an indication of his status as a culturally colonised poet who lives as an African exile in a world which he does not consider as his home. Identifying himself with the African children who have been sold into slavery after being kidnapped from their mother's arms, Al-Fayturi faces the dilemma of bridging the gap between identity and culture. He also confronts the difficulty of writing in a manner that blends his double consciousness as an African and Arab Muslim. On this basis, it is relevant to argue that the difficulty experienced by the poet in reconciling the triangular relationship between language, culture and identity intensifies his sense of exile and dispossession. Al-Fayturi encounters his feelings of alienation and displacement through an affirmation of his African identity celebrating African glories in the past and present. In "Al-Baath Al-Efriqi" ("The African Renaissance") he says:

O dear Africa

the dead body of our history

should be resurrected

It is time for the abandoned Africans

to challenge death

it is time for the sun

to bow in respect of our sacrifices 
It is time for the earth

to listen in awe to our voices

it is time for the earth

to celebrate our joys

since it has witnessed our misery

this is the African era. (Al-Fayturi 1979a: 66, appendix 7)

Unlike other poets from colonised nations in Africa, the Caribbean and the ex-colonies who absorbed the language and culture of the colonisers, Al-Fayturi insists on his ethnic origin as an African celebrating his black identity and glorifying the history of the African people. On this basis, Al-Fayturi aims to dismantle the myth of the dark continent which parallels the noble savage myth of the New World that justified the colonisation and genocide of native races. Identifying himself as a chronicler and a spectator of the tragic consequences of the experience of African people under slavery and colonisation, Al-Fayturi aims to emphazise genuine African traditions. For Al-Fayturi, tradition is integral to his myth-making and his attempt to reconstruct a national African identity. Since tradition, in the words of Henry Giroux (1991: 231), is responsible for shaping "the textual world through which people develop a sense of collective identity and relate to one another," Al-Fayturi's poetry becomes a vehicle for emphasizing the African tradition of resistance and revolt against the invaders. By an affirmation of African cultural values and their role in shaping a nationalist African literature, Al-Fayturi's narrative takes into consideration not only the legacy of slavery and colonisation but also the shifting forces that complete the process of regaining one's identity.

Interconnecting strands of myth and historical fact, Al-Fayturi aims to construct a revolutionary consciousness as a means of renovating and strengthening his African identity. Al-Fayturi's poetry, in other words, establishes a series of narratives of revolutionary nationalism to support Africa's oppressed people. In spite of living in different Arab countries and carrying more than one Arab nationality, he considers himself a black African. Al-Fayturi never feels that he is a stranger to his people, his tribe or traditions regardless of the Arabic language he speaks and the intense acculturation he experiences. In Aghani Ifriqya he identifies himself as a black African who is ready to sacrifice himself for the sake of his homeland:

I am a Negro

I will not allow the white enemy

to occupy my Africa

I am a peasant

and Africa is my land

I have irrigated her soil 
with my blood

I am a free man

my freedom is more precious

than my own children

I am a free man in a free Africa

here I buried my ancestors

and I will be buried here

Africa will remain a black land

may God bless Africa. (Al-Fayturi 1979a: 78, appendix 8)

Apparently, Al-Fayturi's poetry is a reflection of the complex interplay of revolution and the constructs of racism and slavery. His poetry is seen as a project for collective freedom, empowerment and an agent of revolution and regeneration. The conflicting realities and possibilities of Al-Fayturi's interracial background have given rise to intense and agonising debates about the forces which drive him toward Africa and more significantly to controversies over his ambivalent attitude toward Arab culture and identity. The poetry of Al-Fayturi about Africa is a reflection of the dilemma that confronts the black Arab intellectual who is aware of his/her ethnic/African roots. As the grandson of an African slave and an Arab slave trader, Al-Fayturi suffers from an intense identity crisis which splits him apart. Coming from a Sudanese village located on western Sudan near the borders with Chad, Al-Fayturi typifies the Sudanese condition of division and ambivalence. In spite of his interracial descent, Al-Fayturi considers himself a black African poet depicting Africa as a unique continent where people from multiracial and multicultural backgrounds co-exist for ages.

Devoting his poetry to Africa, Al-Fayturi considers himself as an African poet who attempts to blur the boundaries between Africans, Caribbeans and other black people elsewhere in the world. Absorbing the literary heritage of African poets such as "Léopold Senghor and Christopher Okigbo in addition to the works of Langston Hughes and Richard Wright" (Al-Shatti 2001: 9), Al-Fayturi is able to merge elements of poetics and historical fact and create a sense of immediacy in his treatment of a people in crisis. Part of Al-Fayturi's poetry aims to reveal, however, a glorious African past, devastated by the colonisers. For example, in Aghani Ifriqya, he attempts to construct a myth of an African past; a myth which holds the African people from "a dislocation of traditions, a pillar into which they can anchor their sense of continuity and meaningful progress" (Nwoga 1976: 15). Like Al-Fayturi, Hughes tackles the African motif prioritizing issues integral to the African-American experience. In "The Negro Speaks of Rivers", Hughes' persona identifies himself with Africa depicting the bitter experience of slavery and transportation from his homeland in the Congo to be lynched in the American south: 
I am a Negro:

black as the night is black,

black like the depths of my Africa.

I've been a slave:

Caesar told me to keep his doorsteps clean.

I brushed the tools of Washington.

I've been a worker:

under my hand the Pyramids arose.

I made mortar for the Woolworth building.

I've been a singer:

all the way from Africa to Georgia

I carried my sorrow songs.

I made ragtime.

I've been a victim:

the Belgians cut off my hands in the Congo

they lynch me still in Mississippi.

I am a Negro:

black as the night is black,

black like the depth of my Africa. (Hughes 1974: 8)

Affirming his blackness and ethnic roots as an African, the poet expresses his hostility and repulsion at slavery. Further, the attempt of the poet to identify himself with Africa is an "attempt to affirm his humanity" (Essien-Udom 1971: 258). Exploring the history of slavery, the poet refers to the brutalities committed by the western colonisers and oppressors against the African slaves in Africa and the New World: "The Belgians cut off my hands in the Congo / they lynch me still in Mississippi". The poet laments the destiny of the African people under slavery underlining the humiliation suffered by blacks at the hands of the white man: "Caesar told me to keep his door-steps clean / I brushed the tools of Washington." Nevertheless, slavery and colonisation did not break the soul of the black man who has effectively participated in the building of human civilisation: "Under my hand the Pyramids arose / I made mortar for the Woolworth building." In addition to his contributions to humanity in the past and at present, in Africa and in other places the black man never lost his ties with Africa: "All the way from Africa to Georgia / I carried my sorrow songs." Being proud of his music, songs and folk heritage, the black man carried them to America ignoring the hardships of the painful journey from his homeland to the land of slavery.

The poem highlights the image of the black people as historical victims, kidnapped by the Belgian slave traders and sent in slave ships across the Atlantic to be humiliated in the land of the colonisers. But the poem affirms in its beginning 
and end and in its repetition of the words, "Negro", "black" and "Africa", a sense of belonging to the roots: "I am a Negro/black as the night is black/ black like the depth of Africa." As a whole the poem reflects Hughes's use of black rituals and cultural mythology during the Harlem Renaissance in order to link African-Americans with their roots in Africa. Dolan Hubbard (1988: 23) argues that in his poetry Hughes is able to "draw upon the basic Afro-American rituals that grew out of the slave experience which include rituals of toil and despair and regeneration as well as archetypal characters performing endlessly their rituals of defeat, survival and triumph".

Essien-Udom (1971: 258) illustrates the link between African-Americans and their ethnic roots in Africa creating an analogy between the problems that encounter Africans and African-Americans. He also observes that "blacks in Africa and in the New World are unable to come to terms with their crisis of identity and remedy their lack of power". Exploring the historical and human dimension of the relationship between Africa Americans and Africa, Essien-Udom (1971: 258) states:

In his attempt to affirm his humanity, the black American has necessarily turned to his roots. In his attempt to find his roots, he encounters Africa. And he sees that his predicament in America is reflected in the crisis of Africa. The problems that confront Africans today - the crisis of identity, lack of power, and lack of unity - though by no means identical, are in many ways similar to the problems blacks face in America.

As an affirmation of his humanity, the African-American poet evokes Africa in order to establish a link with the roots. Thus, in his early poetry, Hughes reconstructs Africa as a land of glory in an attempt to alter hostile images about Africa and the people of African descent. In other words, Hughes attempts to subvert colonial narratives about Africa, created by western colonisers as a means of justification for the enslavement and suppression of the native Africans. In "The Negro speaks of rivers", Hughes challenges western colonial narratives of Africa as a pre-historic and pagan land establishing a sense of race pride through a restoration of Africa and its culture. Starting with "I've known rivers", the poem evokes the greatness and fascination of Africa as the land of great rivers and ancient civilisations:

I've known rivers:

I've known rivers ancient as the world and older than the

flow of human blood in human veins.

My soul has grown deep like rivers.

I built my hut near the Congo and it lulled me to sleep.

I looked upon the Nile and raised the Pyramids above it. (Hughes 1974: 4) 
Associating black life with the great and ancient rivers of Africa, Hughes evokes black consciousness linking black Americans with their past in Africa. In spite of admitting that Africa belongs to the far past, Hughes views it as a source of black history and traditions. By glorifying Africa as the land of civilisations, Hughes dismantles hostile colonial narratives about the black continent. This process of revision is integral to the Harlem Renaissance spirit when an image of a pre-colonial, a pre-slavery Africa is required for strengthening the black people's sense of dignity and pride. The image of Africa, as a land of fertility and ancient glory is part and parcel of the ethnic consciousness emerging in America in a post First World War era. This image reinforces the racial pride of blacks who no longer feel ashamed of their African origins. As a people of African descent, the black Americans who have witnessed the rise and fall of civilisations and whose souls have "grown deep like rivers" will be able to survive in racist societies like America. In spite of its nostalgia for an African past, "The Negro speaks of rivers" reveals the double heritage of the speaker who writes his poem while crossing the Mississippi evoking the image of Abraham Lincoln as he travels by boat down the river to New Orleans witnessing the suffering of black slaves:

I heard the singing of the Mississippi when Abraham Lincoln

went down to New Orleans, and I've seen its muddy

bosom turn all golden in the sunset.

I've known rivers:

ancient, dusky rivers.

my soul has grown deep like rivers. (Hughes 1974: 4)

The ending lines of the poem provide an impetus to the awakening black consciousness intensifying the speaker's racial pride. The mythic metamorphosis of the mud of the Mississippi into gold is an affirmation of the emergence of a new era where black slaves are transformed into free American citizens as a result of Lincoln's efforts to liberate blacks from slavery. In its intensity and high drama, aggravated by the speaker's movement between his past and present, the poem complicates the issue of identity which is the core of minority literatures all over the world.

Exploring the relationships between African-Americans and their ethnic roots in Africa, Essien-Udom (1971: 233) examines the issue of identity: "Afro-Americans are trying to achieve equality in American society while at the same time striving to maintain three overlapping identities - American in the broader sense, black American in the sense of a unique America experience, and African in the sense of the land of their forebears."

Within the context of the preceding argument, it becomes obvious that Hughes's attitude toward Africa is not only determined by the black American experience but also by his identity crisis which is very deep as a result of his interracial origin. As a mulatto, Hughes suffers from a lack of belonging which he articulates in his poem "Cross": 


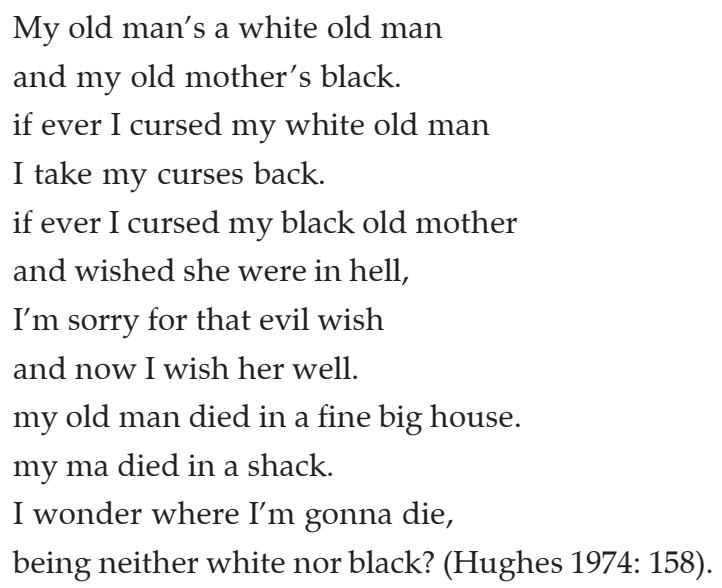

The sense of "being neither white nor black" enhances the poet's identity crisis leading to the splitting of the two parts of his being. The same feeling of loss is captured in "Mulatto" where Hughes creates a dramatic dialogue between the white father and the rejected mulatto:

I am your son, white man!

Georgia dusk

and the turpentine woods.

one of the pillars of the temple fell.

you are my son!

like hell!

the moon over the turpentine woods.

the Southern night

full of stars,

great big yellow stars.

what's body but a toy?

juicy bodies

of nigger wenches

blue black

against black fences.

$\mathrm{O}$, you little bastard boy,

what's a body but a toy? (Hughes 1974: 160).

The entire poetic discourse, mentioned above, affirms the degenerate status of the mulatto and the indifference of the white speaker. The denial of kinship and the affirmation that the mulatto is the product of the oppressor's sexual liaison is a reflection of the brutalities of life in the American South during slavery. The irresponsibility of the white speaker intensifies the mulatto's sense of loss and leads to an identity crisis which never heals. 
Hughes's identity as a mulatto, lost in the labyrinth of American history draws him toward Africa. Sharing the same anguish and racial consciousness with AlFayturi, Hughes expresses a sense of nostalgia for Africa which is captured in his early poetry. Hughes's attitude toward Africa is affected by his identity crisis and his cultural schizophrenia attributed to centuries of separation from his roots. In "Afro-American fragments", Hughes depicts a persona that suffers from an existentialist crisis resulting from being black and American. Due to living in the American society and being exposed to American culture, Hughes's persona no longer has memories of Africa which is viewed as a faraway land. Confronting the dilemma of the disparity between identity and culture, Hughes points out that African blood infuses in him the spirit to write but words flow out of him not in African language but in "strange un-Negro tongue". Capturing the controversial relationship between Africa and the American Negro, Hughes says:

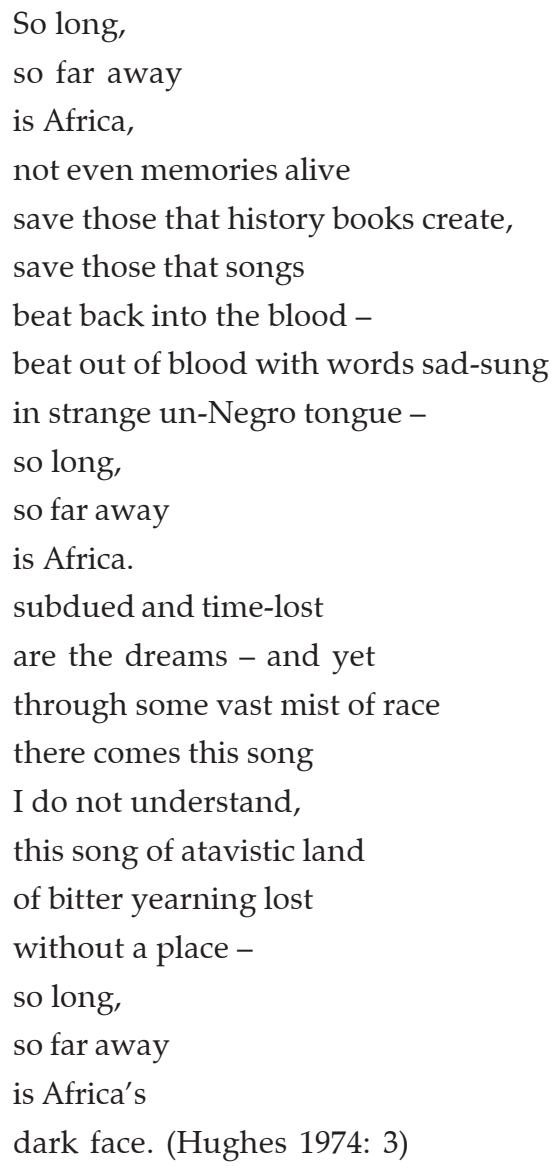

The gap between the poet and his African origins which became deeper and difficult to bridge is one of the consequences of slavery and racism. However, Hugh- 
es's identity crisis which determines his ambivalent attitude toward Africa and America at the same time is shared by other African-American scholars. In Shadow and Act Ralph Ellison (1964: 36) argues: “Like most Americans we are not yet fully conscious of our identity either as Negroes or Americans. This affirmation, of which I speak, this insistence upon achieving our social goal, has been our great strength and also our great weakness because the terms with which we have tried to define ourselves have been inadequate." Apparently, African-American scholars such as Frederick Douglass, DuBois and Ellison have identified themselves as Americans; yet, they did not completely lose connection with their ethnic roots in Africa. The emphasis of the African-American intellectual on Hughes's identity as American is part of the struggle to gain equal rights in the country where he was born:

I too sing America.

I am the darker brother.

they sent me to eat in the kitchen

when company comes. (Hughes 1974: 275)

Expressing a sense of belonging to America, Hughes reveals his ambivalent attitude toward his country:

I am the American heartbreak

Rock on which freedom

Stumps its toe. (Hughes 1974: 9)

Inevitably, the poet's ambivalence toward America leads to his identity crisis which tears him apart. In his early poetry, he struggles to emphasize his American identity. In "Theme for English B", Hughes addresses a racist white teacher affirming that all human beings are equal. Observing that all teachers are white in the place where he studies, Hughes tells the teacher that in America, black and white are supposed to learn from each other:

You are white -

yet a part of me, as I am a part of you,

that's American.

sometimes perhaps you don't want to be a part of you.

but we are, that's true

as I learn from you

I guess you learn from me -

although you're older - and white -

and somewhat more free. (Hughes 1974: 248)

In an attempt to affirm his identity as American, Hughes demands the same rights taken by white people. In "Democracy", he cries: 
democracy will not come

today, this year

no ever

through compromise and fear.

I have as much right

as the other fellow has

to stand

on my two feet

and own the land

freedom

is a strong seed

planted

in a great need

I live here too.

I want freedom

just as you. (Hughes 1974: 285)

Nevertheless, the poet's dreams to obtain his rights as an American citizen are undermined by American racism and oppression. Therefore, Hughes turned toward Africa, particularly after the Harlem Renaissance era, when his aspirations were frustrated by the mainstream racist policies. Like other African-American writers who turned to their ethnic roots in Africa seeking refuge in movements such as Negritude, pan-Africanism and other forms of black nationalism, Hughes has not been able to reconcile the two parts of his mutilated self. Due to his identity crisis he develops an ambivalent attitude toward his homeland, therefore, his poetry on Africa becomes an expression of an extreme condition of alienation which Isaac Yetiv (1976: 87) views as "the denouement of the hybrid's tragedy - the static condition which terminates the identity crisis".

Discussing the identity crisis which characterizes the literature of minority writers, Erik Erikson (1968: 297) argues:

The widespread preoccupation with identity, may be seen not only as a symptom of "alienation" but also as a corrective trend in historical evolution. It may be for this reason that revolutionary writers from national and ethnic minority groups (like the Irish expatriates or our Negro and Jewish writers) have become the artistic spokesmen and prophets of identity confusion. Their artistic creation goes beyond complaint and exposure, and it includes the moral decision that a certain painful identity-consciousness may have to be tolerated in order to provide the conscience of man with a critique of conditions, with the insight and the conceptions necessary to heal himself of what most deeply divides and threatens him, namely his division into what we have called "pseudospecies". 
The dilemma of the African-American writer, his//her) identity crisis, stems from the fact of being black living in the American Diaspora. The identity crisis becomes painfully obvious in the literary works of African-American writers because they suffer at times from a cultural schizophrenia which creates a conflict in the psyche of the black American who is torn between his past and present:

He would not Africanize America, for America has too much to teach the world and Africa. He would not bleach his Negro soul in a flood of white Americanism, for he knows that Negro blood has a message for the world. He simply wishes to make it possible for a man to be both a Negro and an American, without being cursed and spit upon by his fellows, without having the doors of opportunity closed roughly in his face (DuBois 1968: 17).

Apparently, the integrationist stance implicit in the "double consciousness" concept as indicated above by DuBois is different from the nationalist perspective enunciated by Martin Delaney and Bishop Henry Turner from the late nineteenth century and advocated by Marcus Garvey in the early decades of the twentieth century. The heroic struggle of the newly independent African countries and the racial turmoil of the 1960s encouraged the radical rhetoric of people like Malcolm $X$ which affected the issue of black identity. In this respect it is also relevant to argue that Martin Luther King's integrationist solution to the black identity crisis is rejected by black radical movements that called for separation and PanAfricanism. In spite of the fact that Hughes was not directly involved in this ideological debate, the crucial events in Africa and America during the post-World War II era have an impact upon his treatment of the African motif. Obviously, Hughes' early poems about Africa were written about a world which existed in the poet's fantasies. Besides, the image of Africa in these poems was integral to the spirit of the Harlem Renaissance when an image of a heroic, pre-slavery Africa provided an impetus for the black people in America. In other words, Hughes's propagation of the romantic image of Africa as the land of ancient civilisations reinforced the new ethnic consciousness of African-Americans which emerged after the First World War. In this context, Hughes's image of a pre-colonial and civilised Africa aims to undermine the colonial narrative about Africa as a pagan land belonging to pre-history.

Due to complex developments resulting from the rising of nationalist liberation movements in Africa in addition to the racial turmoil in America in the post-World War II era, the fanciful image of Africa which permeates Hughes's early poetry disappears to make way for a more realistic Africa, the post-colonial Africa of Kwame Nkrumah and Patrice Lumumba. In "Lumumba's grave" from the collection The Panther and the Lash (1967), the romantic image of Africa is replaced by a realistic image which reflects the African struggle for independence in the era of de-colonisation: 
Lumumba was black, his blood was red and for being a man they killed him dead, they buried Lumumba, in an unmarked grave, but he needs no marker my heart's his grave, and it's marked there, tomorrow will mark it everywhere. (Hughes 1967: 66)

In Hughes's post Harlem Renaissance poetry, the romantic longing for Africa, inspired by the poet's imagination, is greatly undermined to be substituted by an embittered Africa for whom

the past has been a mint

of blood and sorrow

that must not be

true of tomorrow. (Hughes 1967: 69)

In other words, Hughes, in his later poetry, gives priority to issues integral to the existence of Africans in different parts of the dark continent. Urging the African people to revolt against colonisation and oppression, Hughes (1967: 13) states:

Quick sunrise, come!

Sunrise out of Africa

Quick come!

Sunrise, please come!

Come! Come!

In "Johannesburg mines" from Good Morning Revolution (1973) he reveals an intimate attachment to Africa denouncing the enslavement and exploitation of the black people by the capitalist South African regime:

In the Johannesburg mines

there are 240,000 natives working.

what kind of poem

would you make out of that?

240,000 natives working

in the Johannesburg mines. (Hughes 1973: 10) 
Like Hughes, Al-Fayturi is attached to Africa; nevertheless, his relationship with his homeland is determined by other factors. In other words, the experience of colonisation not only triggers Al-Fayturi's revolutionary ideology but also affects his attitude toward Africa. He believes that until the beginning of colonisation, there was no difference between North Africans and South Africans. Looking at Africa from a precolonial perspective, Al-Fayturi sees no distinctions between what is called IslamoArabic Africa and the rest of Africa south of the Sahara. To Al-Fayturi, the division of Africa is artificial since the Sahara desert is not considered as a barrier between the two parts of Africa. In a pre-colonial Africa, there were no boundaries for races and religions that coexist in the continent as a whole. Judaism, Christianity, Islam and other religious beliefs are part of the African mosaic where Christians, Muslims, Arabs, Africans and others from a variety of ethnicities spread all over the continent. Al-Fayturi considers Africa as a unified homeland which incorporates all black people expressing pride in his African roots. In "Hadatha fi Ardi" ("Happened in my land") he says:

I own nothing except my faith

in my people, in the history

of my homeland, Africa

I carry Africa in my blood. (Al-Fayturi 1979a: 108, appendix 9)

In Ashiq min Efriqya the poet associates his feelings of pain, alienation and bitterness with his homeland which is personified as his beloved:

$\mathrm{O}$, Africa

you have been my torture

my alienation

but when I started to sing

I dedicated my songs

to your beautiful eyes

in your eyes I saw

the flames of pain

in your eyes I saw

suffering, pride and dignity. (Al-Fayturi 1979a: 355, appendix 10)

The depiction of Africa as the poet's beloved does not aim to romanticize the colonised continent. However, in the Arabic poetic tradition, one's homeland is frequently introduced in feminine and romantic terms. Seeking redemption and refuge in Africa, Al-Fayturi links his own history as a black exile with the tragic history of Africa. Further in Ashiq min Efriqya the poet expresses longing for return to a precolonial Africa, uncorrupted by colonisation. Pursuing salvation in an Africa which does not suffer from the wounds of slavery and the curse of colonisation, the poet seeks forgiveness and re-union after his long absence: 


\author{
Forgive me Africa \\ I have nothing to give you \\ except the ruins \\ of my poem \\ forgive me Africa \\ and take me in your wounded bosom \\ put me on your throne \\ located on the mountains \\ between the clouds and the wind \\ your sun is a blue diamond \\ twinkling on your wounded bosom \\ forgive me Africa \\ I am running out of breath \\ my soul is a cloud \\ my body melts in \\ the rays of the dusk. (Al-Fayturi 1979a: 337, appendix 11)
}

The poet's feelings of nostalgia and allusions to the mountains, the clouds, the winds and the blue sun recall images of Africa reminiscent of its portrayal in African-American and Caribbean poetry where the black continent is romanticized. Nevertheless, the agonised poet attempts to depict an Africa which used to be a peaceful place until it was ravaged by colonisation and slavery. In the poem cited above, colonisation is associated with wounds, chaos and humiliation while pre-colonial Africa is viewed as a peaceful paradise.

Therefore, Al-Fayturi castigates western colonial countries which promoted slave trade bringing havoc and curse to Africa. Reaching down to the roots of African history, he endows his poetry with images of myth and pre-history. In his agony, the colonised poet reproduces African images embedded in personal and ethnic psyche exploring geographical and natural features of an invaded and conquered continent. Viewing Africa as a victim of mercantile civilisation and colonial hegemony, he calls for a saviour or a black prophet to terminate oppression. In his poem "Al-Afaa" ("The snake") the poet says:

O Africa

you dream as if you were

a snake sleeping in relaxation

on the yellow sands of the steaming desert

you dream of a black knight

a black saviour

proud of his blackness

proud of the desert heat 
which turns him into a free man

a black prophet

in his steps lying

pride and greatness (Al-Fayturi 1979a: 133-134, appendix 12)

According to Al-Fayturi, the colonial invaders not only destroyed the beauty of Africa but also brought anarchy and chaos to the land. Therefore, the colonisers are delineated in negative terms as agents of destruction who show no respect for African culture and traditions. Transforming the African people into a nation of slaves and outcasts, the European colonisers and slave traders aim to banish the African people outside human history. Depicting the tragic experience of slavery Al-Fayturi in "Ahzan Efriqya" ("African sorrows") uses a slave persona to express his feelings of pain and humiliation over the plight of the African people:

\author{
Alas! Africa \\ I will be taken away from your arms \\ and the fence of time will separate us \\ my steps will take me \\ to unknown lands \\ my journey will have no end \\ but I will keep you \\ in my eyes \\ day and night \\ farewell Africa \\ my lost paradise. (Al-Fayturi 1979a:185, appendix 13)
}

Through intensive poetic utterances, Al-Fayturi smashes colonial mythology celebrating Africa as the land of civilisations. He denounces slavery and racism creating a binary opposition between the peace of a pre-colonial Africa and the chaos brought by the colonisers. Tracing the tragic consequences of the European intrusion and invasion on the African people, the poet highlights the psychological ramifications of colonisation on African psyches underlining the scars left on those involved in the war with the colonisers. He points out that European conquest of Africa has damaged the cycle of nature in the virgin continent. According to the poet, the beauty of a pre-colonial Africa is destroyed by the machines of the European colonisers. The natural texture and the ecological balance of Africa are invaded by a mercantile economy in which Africans themselves are turned into commodities, transported across the ocean to become slaves in alien lands. In "Thawrat Qarah" ("Revolution of a continent") from his volume Aghani Efriqya, Al-Fayturi says: 
When I asked: where are they going?

they answered: to a remote land.

when I asked: Will they come back?

the echo of their voices died

on their African lips. (Al-Fayturi 1979a: 70, appendix 14)

In "Hadatha fi Ardi" from Aghani Efriqya, Al-Fayturi describes the African harbours which witnessed the arrival of the military vessels of the colonisers and the departure of the slave ships carrying the people of Africa to unknown shores in their journey of no return:

Ships are coming toward the harbour

loaded with weapons

and others are leaving the shores

carrying my countrymen

carrying the treasures of my land

the treasures of my history

when the slave ships appeared in the horizon

my homeland entered the era of misery

one day Africa was enslaved

moving from slavery into slavery

moving from prison into prison. (Al-Fayturi 1979a:110, appendix 15)

Al-Fayturi states that due to slavery and colonisation, Africa enters into the dark ages, therefore, in "Al-Layl wa Al-Hadikah Al-Mahjourah" ("The night and the deserted garden") from Aghani Efriqya, he refers to what he calls "the eternal African night" (Laylu Efriqya Al-Abadi) which has no end:

It is the African night

the night of crowned and naked slaves

lying like statues

in the land of $\sin$

where slaves are sinners and prophets

killers and victims

we are the African slaves

with thick lips

feverish and red

carrying the ancient sin

the painful wounds

while the mills of fate

are grinding our bones. (Al-Fayturi 1979a: 114-115, appendix 16) 
Using Christian imagery, in the preceding lines, Al-Fayturi refers to the crucifixion of the African people under the whips of slave traders and European invaders. The allusions to the sin motif and the painful wounds of slavery identify the black slaves with Christ on the cross. Africa is viewed as the land where the sin of slavery takes place and where "the mills of fate" (tawaheen Alkadar) crush the bones of the naked Negroes. In "Al-Afaa" the poet describes Africa under slavery as

an extensive graveyard

stretching across the horizon

Africa is a graveyard

which has no end

its naked slaves

are dying out of sadness

out of toil. (Al-Fayturi 1979a: 131, appendix 17)

Unlike Hughes and other black poets who attempt to romanticize Africa, Al-Fayturi rejects a poetics which romanticizes the past. Depicting Africa in the precolonial era, the poet does not aim to express feelings of nostalgia or to romanticize the past. Instead, he attempts to uncover the tragic consequences of slavery and colonisation on the psyches of the African people. In "Aqwal Shahid Ethbat" ("Testimonies of an eyewitness") the poet says:

I will make a confession

for our future generation

I have witnessed the massacre

of the modern times and I did nothing. (Al-Fayturi 1979b: 68, appendix 18)

In this context, Al-Fayturi's testimony reveals that the brutalities and massacres committed by the colonisers turned Africa into a graveyard. He also denounces colonisation which turned Africa into a continent of outcasts, exiles and refugees emphasising the chaotic impact of eras of colonisation and domination on Africa. The frustrated poet addresses his beloved homeland in "Al-Tufan Al-Aswad" ("The Black Flood") saying:

Africa, land of slaves

they have turned you into

a massive graveyard

your people

were trodden by the horses of the invaders

Africa

you became the ruins of a polluted myth

spat out by the lips of the colonisers

Africa you have become the land of slavery

the land of the poor and the naked. (Al-Fayturi 1979a: 90, appendix 19) 
In his depiction of Africa, Al-Fayturi captures the tragic consequences of colonisation on Africa which is transformed into a wasteland where

cactus bloomed

above our ancient tomb

the little cactus lavishing its black shade

on our remains

as if not satisfied with our estrangement

it imbibes all our souls distill

and stretches above us its hard branches

conveying them with shroudless corpses (Al-Fayturi in Khouri 1973: 155).

Al-Fayturi's image of Africa as a wasteland aims to shock the reader and subvert the romantic portrayal of the dark continent by other poets. The tendency of postcolonial poets from African origin to romanticize the African past, according to Al-Fayturi, leads to feelings of alienation and a false sense of nostalgia. Therefore in "Aqwal Shahid Ethbat" he captures the painful realities of African life:

My lips were full of cries

I burst into tears

the assassins, the tartars and the victims

the weapons of crime

the adulterers have usurped power

and the banners of revolution

were buried in the mud

my homeland was cursed with

colonisation

even the graves of my land

were colonised. (Al-Fayturi 1979a: 67, appendix 20)

Recalling the eras of slavery and colonization, Al-Fayturi digs deep into the womb of African history denouncing the lack of remorse on the part of European colonizers for the barbaric punishment inflicted on the African people. Apostrophising Africa and blaming her for allowing the invaders to enslave the African people, AlFayturi, however, expresses a vision of a devastating revolution which will demolish the foundations of imperialism in Africa. In "Al-Tufan Al-Aswad" he points out:

Africa, land of slaves

do you hear the sad songs of the slaves

roaring with anger

Africa

do you see the faces of the Negroes

laughing loudly around the coffins

of the tyrants. (Al-Fayturi 1979a: 89, appendix 21) 
Revealing a prophecy of an inevitable African rebellion and calling for revolution and protest against the western colonizers, Al-Fayturi urges Africa to be liberated from colonial fetters and wake up from her historical slumber. In "Al-Baath AlEfriqi" ("The African Renaissance") he says:
wake up Africa
wake up from your nightmare
throw away the master's yoke
wake up Africa
you have been crushed
under the master's heavy feet
you have been isolated

in your tired cottage. (Al-Fayturi 1979a: 61, appendix 22)

Challenging western imperialistic mythology which aims to erase Africa's pre-colonial history, Al-Fayturi creates an African poetics, in Arabic orthography in order to dismantle narratives of enslavement and hegemony. In his poetry, Al-Fayturi foregrounds the totalizing impact of western imperialism on African history interrogating western discourses which aim to degrade the African people. Therefore, his poetry undercuts the false premise that Africa is a pre-historic continent and the land of barbaric races. Engaging in a rethinking process which contributes to the current reconsideration of African history, Al-Fayturi's counter-poetics attempts to reveal rather than conceal the social and political realities about Africa:

sadness and loss

silence and regret

were embracing a poet consumed by struggle

for poetry is a stranger in my land

killed by emptiness and void. (Al-Fayturi in Khouri 1973: 155)

As passionate and dramatic portraits of psyches in the agonies of death, his poetry depicts the consequences of the sense of humiliation and trauma undergone by the African people under slavery and colonisation. In his candid creation of portraits of psyches in the agonies of death, Al-Fayturi explores the impact of colonial violence on African people. Denouncing colonialism and the exploitation of blacks by western colonisers, Al-Fayturi's poetry offers a flexible instrument for coping imaginatively with the trauma of the African experience. His poetry is a cry of revolt against racial oppression and the brutalities of an obnoxious colonisation which caused adverse damage to the historical memory of Africa. In "Al-Bath Al-Efriqi" he apostrophises Africa urging her to revolt against the invaders: 
wake up Africa

do not lick the shoes of the invaders

do not send the caravans of slaves

to the land of the white colonisers. (Al-Fayturi1979a: 64, appendix 23)

In "Ahzan Al-Madinah Al-Sawdaa" ("Sorrows of the Black City") from Aghani Efriqya Al-Fayturi speaks about Africa under colonisation and slavery as a continent "without pride or glory" (qarah bela karama aw magd) urging Africa to be delivered from the fetters and "darkness of slavery" (zalam alubudiyyah). Under slavery, Africa is delineated as a poor land where

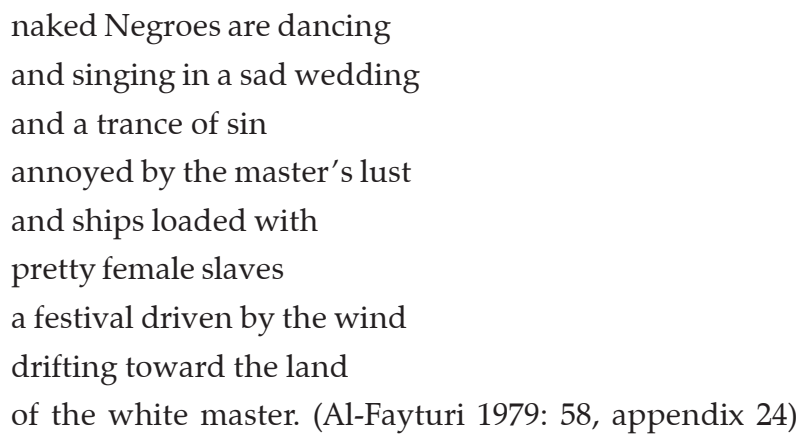

Calling all Africans to be committed to revolution and struggle for freedom and independence, Al-Fayturi reflects not only his individual commitments to Africa but also the collective experience of the African people. He believes that writing about the plight of the African people is an expression of an alliance with what Frantz Fanon calls "the wretched of the earth". In "Nkrumah " from Ashiq min Efriqya he says:

My words are bodies of victims

crucified on the roads

my words are pregnant bowels

twisting under the stabs of daggers

my words are voices of life

that never know the meaning of death

my words are African revolutions

my words are African people with

Negro features. (Al-Fayturi 1979a: 354, appendix 25)

Al-Fayturi's antipathy toward slavery and colonisation is an outgrowth of his loathing for western/European policies of exploitation which target the African people for centuries. He considers the dehumanization of the African people by western colonial powers as repugnant to the laws of nature and the principles of 
morality. In "Laylatu alsabet alhazeen" ("Sad Saturday Night") he views Africa under colonisation and slavery as

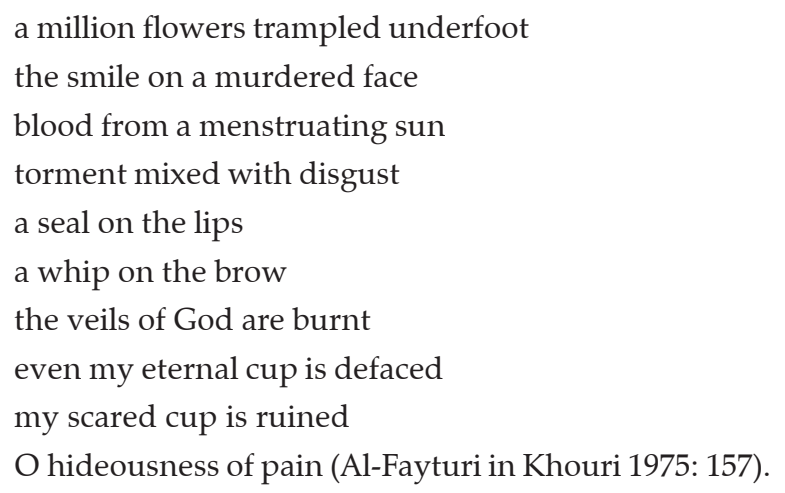

In the same poem, cited above, Al-Fayturi depicts Africa, under colonisation, as a location of crucifixion where the branches of African trees are seen as a network of crosses. The poet also makes references to "corpses imprisoned by a wall" and "a dark wall" which "buries us, digs our grave twice daily" (Al-Fayturi in Khouri 1975: 157). These pessimistic images of Africa are reflections of the poet's vision of a brutal colonisation and racial oppression aiming to damage the collective psyche of Africa. In this context, Al-Fayturi's poetry offers a flexible instrument for dealing imaginatively with the trauma of the African experience as he denounces the suppression of the people of Africa not only by the colonial war machine but also by the culture of fear and silence enforced by the colonisers. He also condemns the policy of legalised brutalization, political terrorism, pain and death practiced by the colonial powers against Africans. Further, Al-Fayturi categorizes colonial violence not only as inhuman acts of individual aberration but also as the essence of colonial politics which destroyed Africa and its cultural peculiarities. In "Aqwal Shahid Ethbat" he says:

I am making a confession

I have seen the assassins

they were roaming like birds of prey

they consider themselves our judges,

judges carrying the weapons of death

they tore our sacred books. (Al-Fayturi 1979b: 64, appendix 26)

Like Hughes, Al-Fayturi affirms that the painful experience of enslavement and colonisation turned the black people of Africa into a nation of exiles and outcasts. Nevertheless, the same experience brings about enormous consequences which bind the black people together triggering literary interaction between black writers from different parts of the world. In their attempts to confront the totalising and hegemonic powers, which aim to erase the identity of their people, Al-Fayturi 
and Hughes explore areas of overlap drama between the painful experience of AfroAmericans and the catastrophic history of black Africans. Reconstructing the image of Africa as the land of ancient civilisations, the two poets dismantled colonial narratives which aim to banish Africa outside human history. In their poetry, they also integrate narratives of identity and Diaspora in order to express a feeling of nostalgia and longing for return to the roots.

\section{Notes}

1. Al-Fayturi wrote many poetic collections in the post-World War II era dealing with the painful experience of black people in Africa and Diaspora such as Aghani Efriqya ("African Songs", 1955), Ashiq min Efriqya ("Lover from Africa", 1964) and Uthkurini ya Efriqya ("Remember me Africa", 1966) collected in Diwan Al-Fayturi ("The Complete Poetic Works", volume 1, 1979). He also wrote a poetic drama about eighteenth-century slavery in Africa entitled Ahzan Efriqya ("African Sorrows", 1969) collected in Diwan Al-Fayturi ("The Complete Poetic Works", volume 2, 1979).

The poet was born in 1930s, in a village called Al-Jiniya, located in western Sudan near the borders with Chad and Libya. His father descended from a Libyan family who escaped to Sudan after the fascist occupation of Libya prior to the First World War. His mother was the daughter of a rich slave trader from a famous Arabian tribe. His grandmother, Zahra, was a black slave who gained her freedom after marrying his grandfather, the Arabian slave trader. During the Second World War, Al-Fayturi's family moved from Sudan to Egypt where they stayed in the city of Alexandria. Living in Alexandria in the 1940s, Al-Fayturi witnessed with pain the humiliation of the black people recruited from Sudan and other African countries and forced to tackle insulting jobs and work as servants for the European soldiers during war. This experience intensifies AlFayturi's identity crisis and enhances his ethnic consciousness as black and African. In spite of living in different Arab countries, Al-Fayturi does not consider himself an Arab but a black African poet who is committed to defend the rights of the black people all over the world. As a young poet, Al-Fayturi came under the influence of African-American writers particularly Langston Hughes and Richard Wright in addition to other African and Caribbean scholars and poets. Due to his pioneering works, critics consider Al-Fayturi as the first poet who sings for Africa and black people in Arabic.

Further, Al-Fayturi was influenced by the popular biography of Antara Ibn Shaddad, Al-Absi, the black pre-Islamic folklore hero who lived in tribal Arabia and suffered under slavery. Antara's epic biography which has become part of the Arabic folklore heritage provides a source of inspiration for Al-Fayturi. Revealing sympathy toward Antara as a black revolutionary figure, victimized by slavery, Al-Fayturi emerges as a defender of the black race in Africa and the Arab world. Antara, the black son of a noble tribesman from Arabia and a slave woman, was subjugated to different forms of humiliation including the betrayal of his father who denies his paternity and considers him as a slave living in his household. As a young man, Antara was famous for his poetic talent and war adventures. He was a talented poet who composed famous epics dealing with tribal life. He was also a great warrior who defended his tribe against the invasions of the enemies. Due to his kindness and heroism, Abla, the most beautiful girl of the noble tribe of Abs, fell in love with him in spite of being a black slave. The love story between Antara and Abla created tribal tensions because marriages between slaves and free women were forbidden in pre-Islamic Arabia. Antara's suffering and internal conflict were settled only when he was liberated from slavery. Antara became a free man when his father acknowledged him as his legitimate son expressing his deep regrets for abandoning him as a child and a young man. The reconciliation between son and father paved the way for the marriage of Antara and Abla, his beloved, for whom he wrote his love epics.

The story of Antara raises the issue of the nature of slavery in the Arab world and the Middle East. In this context it is relevant to argue that slavery in the Arab world during the pre-Islamic era was different from slavery in the West or the Americas or elsewhere because slaves were dealt with as servants or housemaids, however they were denied most of their rights including citizenship. Though the tribal system in Arabia offered them some rights given to free people slaves were 
considered as inferior. Islam attempts to put an end to slavery and many of Prophet Mohamed's close friends were slaves, brought from Africa prior to Islam. However, the argument that Islam eliminates colour racism is a simplification of history. In Muslim communities in the Middle East and Africa, there are two kinds of slavery (white slaves and black slaves) and colour prejudice without caste. Under the Ottoman regime of Mohamed Ali, for example, Mamlukes (white slaves) were used as soldiers to defend the state. In other parts of the Arab world, black slaves were used as domestics and manual labourers. From the $8^{\text {th }}$ century until the $14^{\text {th }}$ century, Arab raiders attacked sub-Saharan Africa kidnapping Africans who were forced to become slaves. Slave markets were famous in different parts of Arabia and in Morocco blacks from West African origin were imported and sold into slavery until the $19^{\text {th }}$ century. The distinctive feature of slavery in the Islamic world is not its racial aspect but its military and administrative nature. Slavery in AraboIslamic countries has no Jim Crow laws but undoubtedly it has its own traditions of prejudice and racism. From a historical perspectives it is well-known that racial and colour prejudices were integral to Arabo-Islamic traditions. For example, prisoners of war who were captured in battles between the Muslim people and the invading armies during the early Islamic era were considered as slaves / concubines regardless of their colour and origin. In spite of considering slavery as a religious taboo, and a sacrilegious crime sufficient to get its advocate out of the Islamic doctrine, slavery continued to take different forms in the Arab world particularly in Arabia until the middle of the $20^{\text {th }}$ century.

2. All translations from Arabic prose and poetry are done by the writer unless names of other translators are mentioned in the text and the works cited.

3. Al-Fayturi came under the influence of Langston Hughes and Richard Wright in addition to other black scholars and writers from Africa and the Caribbean. In his comprehensive study, AlAdab Al-Ifriqiyyi ("African Literature") Ali Shalash (1993) traces the literary dialogues between black African writers and their counterparts in the Diaspora, Abdul Fattah Al-Shatti (2001) specifically explores the impact of Hughes on Al-Fayturi.

4. See Al-Fayturi's (1979a: 5-36) introduction to his Diwan, "On My Poetic Experience". See appendix for the original Arabic texts cited chronologically as they appear in the article.

5. Najuib Saleh emphasizes Al-Fayturi's insistence on writing about the African and African American experience of colonisation and enslavement in Arabic. See Saleh's Mohamed Al-Fayturi wa AlMaraya Aldairiyya (1984).

\section{Works cited}

Al-Fayturi, M. 1979a. Diwan Al-Fayturi ("The Complete Works of Al-Fayturi”, Vol. 1). Beirut: Dar Alawda.

1979b. Diwan Al-Fayturi ("The Complete Works of Al-Fayturi”, Vol. 2). Beirut: Dar Alawda.

Al-Shatti, Abdul-Fattah. 2001. Shi'r Al-Fayturi: Al-muhtawa wa Al-fan ("The Content and the Art of Al-Fayturi's Poetry"). Cairo: Dar Qebâ.

Barksdale, Richard K. 1977. Langston Hughes: The Poet and His Critics. Chicago: American Library Association.

Bracey, John H. 1971. Black Nationalism since Garvey. In Nathan I. Huggins (ed.). Key Issues in the Afro-American Experience. New York: Harcourt Brace Jovanovich, 259-279.

Cruse, Harold.1968. Rebellion or Revolution? New York: William Morrow.

DuBois, W. E. B. 19682. The Souls of Black Folk. New York: Fawcett.

1947. The World and Africa. New York: Viking Press.

Ellison, Ralph. 1964. Shadow and Act. New York: Random House.

Erikson, Erik E. 1968. Identity: Youth and Crisis. New York: W. W. Norton and Co., Inc.

Essien-Udom, E. U. 1971. Black Identity in the International Context. In Nathan I. Huggins (ed.). Key Issues in the Afro-American Experience. New York: Harcourt Brace Jovanovich, Inc., 233-258.

Giroux, Henry A. 1991. Postmodernism, Feminism and Cultural Politics: Redrawing Educational Boundaries. Albany: State University of New York Press.

Goha, Michele. 1999. Al-Shir Al-Arabi Al-Hadith ("Modern Arabic Poetry"). Beirut: Dar Alawda.

Hubbard, Dolan. 1988. Call and Response: Intertextuality in the Poetry of Langston Hughes and Margaret Walker. The Langston Hughes Review 7: 22-30. 
Hughes, Langston. 1926. The Weary Blues. New York: Knopf. . 1967. The Panther and the Lash. New York: Knopf.

. 1973. In Faith Berry (ed.). Good Morning Revolution: Uncollected Writings of Social Protest by Langston Hughes. New York: Lawrence Hill. . 1974. Selected Poems of Langston Hughes. New York: Vintage.

Khouri Monah \& Algar, Hamid (ed. \& trans.). 1975. An Anthology of Modern Arabic Poetry. California: University of California.

King, Martin Luther, Jr. 1969. Chaos or Community? London: Penguin Books.

Nwoga, Ibe. 1976. The Limitations of Universal Critical Criteria. In Rowland Smith (ed.). Exile and Tradition. Studies in African and Caribbean Literature. London: Longman, 8-30.

Saleh, Najuib. 1984. MohamedAl-Fayturi wa Almaraya Aldairiyya ("MohamedAl-Fayturi and the Circular Mirrors"). Beirut: Dar Aladab.

Shalash, Ali. 1993. Al-Adab Al-Ifriqiyyi ("African Literature"). Kuwait: Alam Almârefa.

Yetiv, Isaac. 1976. Alienation in the Modern Novel of French North Africa Before Independence. In Rowland Smith (ed.). Exile and Tradition: Studies in African and Caribbean Literature. London: Longman, 85-97. 


\section{Appendix}

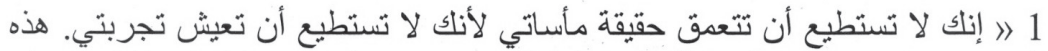

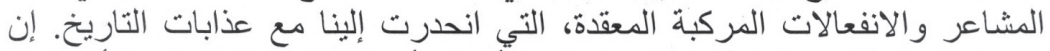
بصمات عهد العبودية تركت آثار ها على الآرواح أيضاً، وليس فقط على اللى الأجساديان.

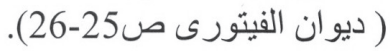

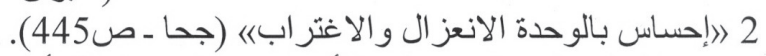

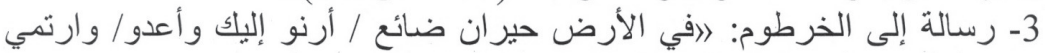

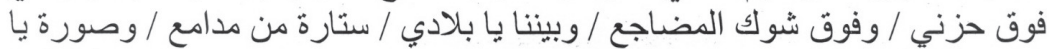

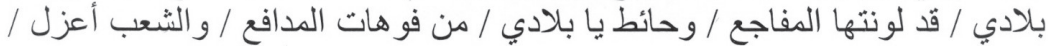

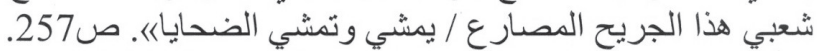

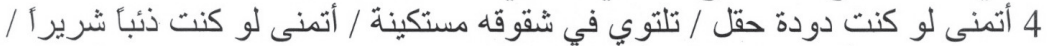

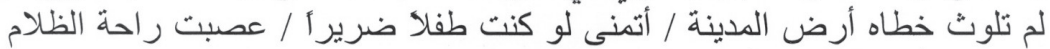

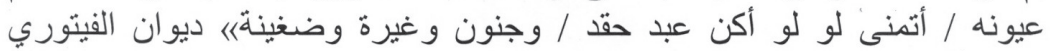
5 إإن الثعر هو لغتي وشعاري الثورة وسلاحي الحقيقة. أنا أول شاعر غنى

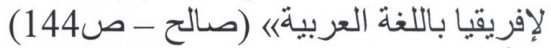

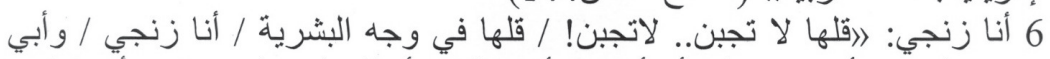

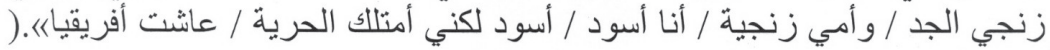

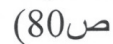

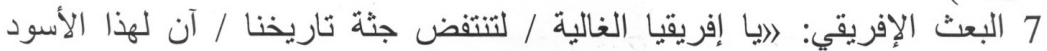

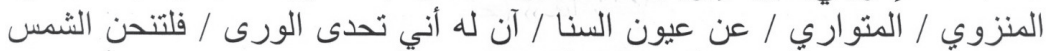

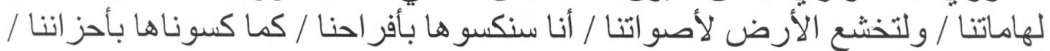

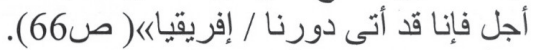

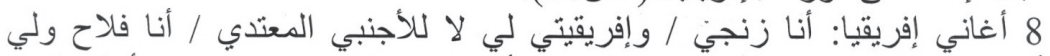

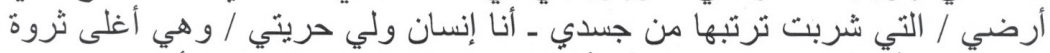

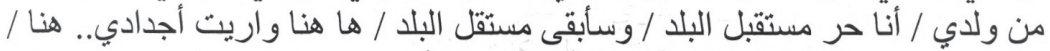

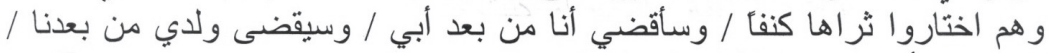

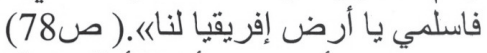

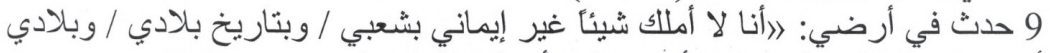

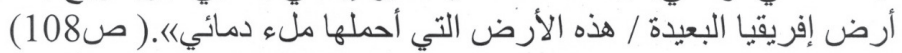

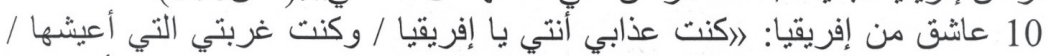

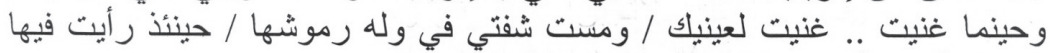

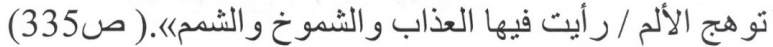

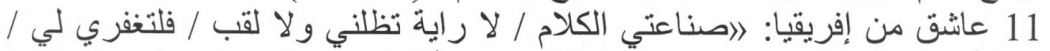

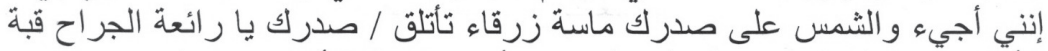

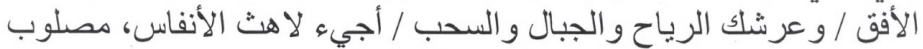

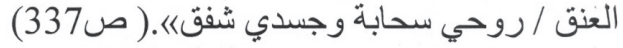




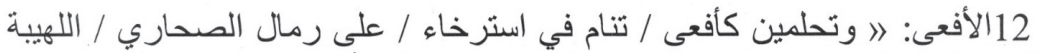

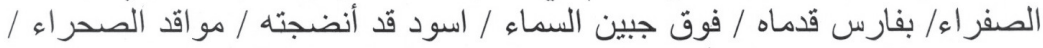

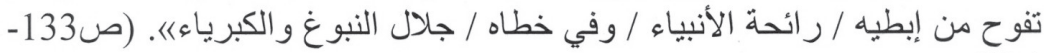

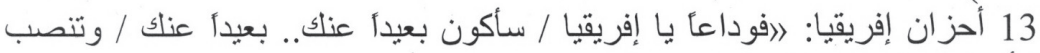

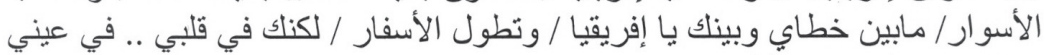

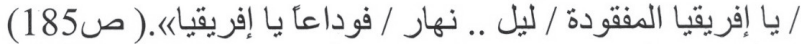

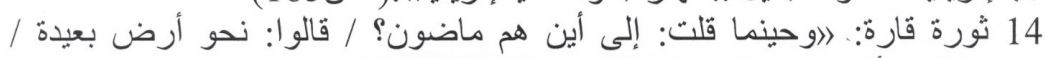

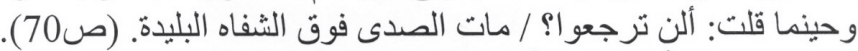

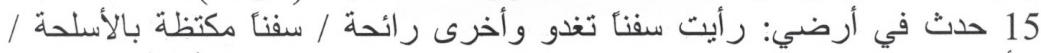

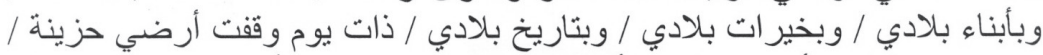

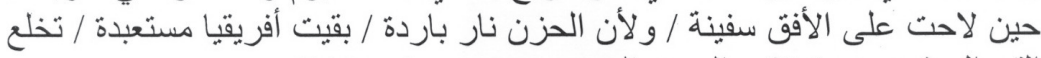

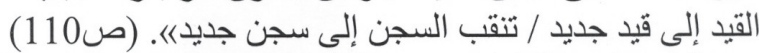

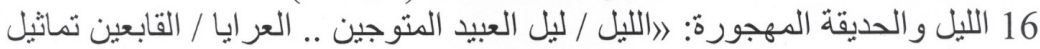

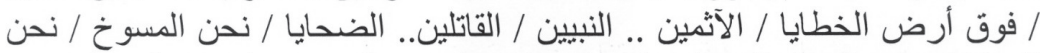

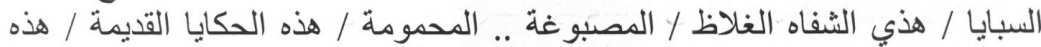

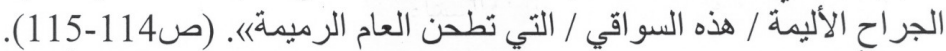

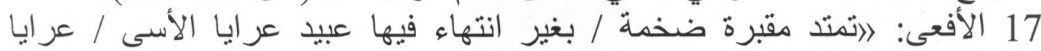

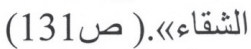

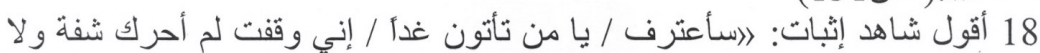

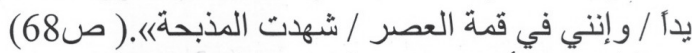

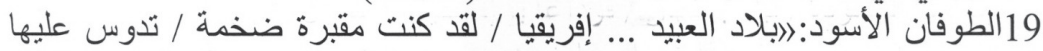

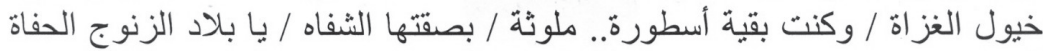

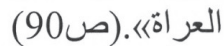

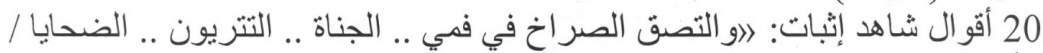

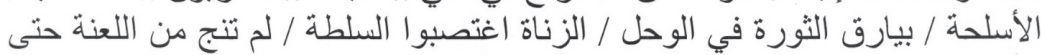

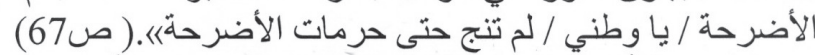

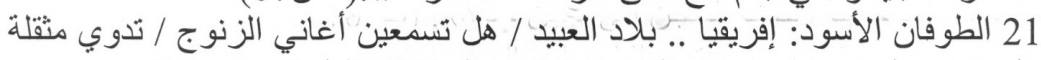

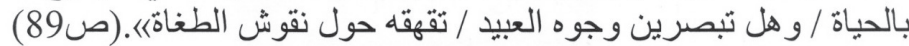

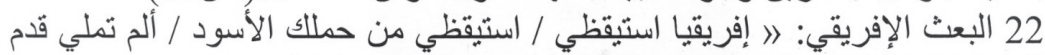

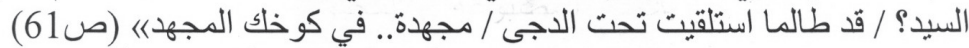

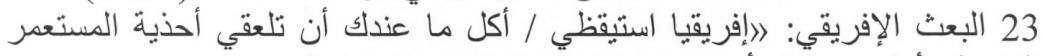

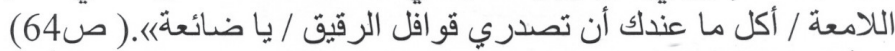

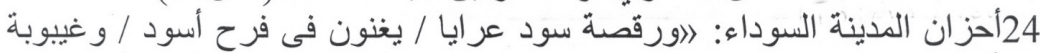

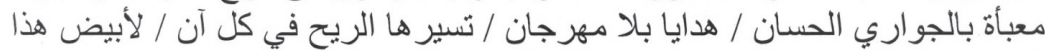

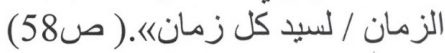

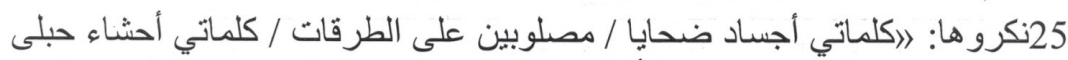

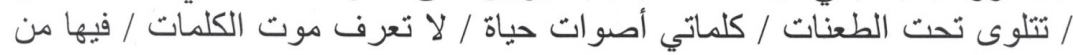

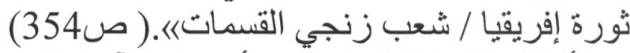

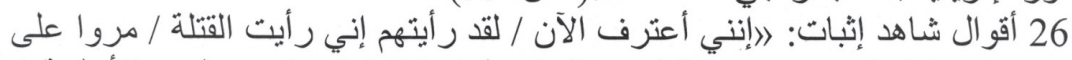

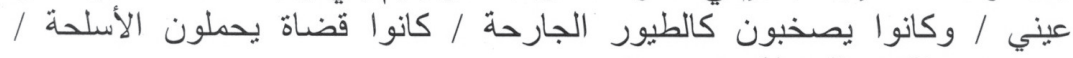
ويمضغون الكتب المنزلة)،.(ص64) 